penetrating to the Independent Indians of Eastern Yucatan from the western part of the peninsula, which remains Mexican. But should this not be possible from Belize (British Honduras) ? I have heard that the coloured people of the colony trade with the Mayas. Would it be possible then to obtain some information in this way?

As to the interest of a visit to the Maya country by an educated traveller it would bear especially ( $\mathrm{I}$ ) on the condition of the people since they are free from their white masters. How does it compare with the condition of the Mayas of Western Yucatan, who live in a de facto serfdom to the large landowners? (2) The antiquities, of which we have a description by Stephens, but certainly would know more. Very likely the Mayas will allow a white man who is not a Spanish-American to travel in their country; they have no special reason to hate anybody except the latter.

Jurschtatskaya, 9, St. Petersburg, March 25

\section{Deltaic Growth}

IN reference to the question as to the amount of sediment brought down by Delta Kivers, I had occasion in 1877 to ascertain the amount of sediment carried by the waters of the River Plate, and found it to amount to the $\frac{1}{77^{3}}$ nd part by weight. Mr. J. F. Bateman, the well-known hydraulic engineer, in his report on the proposed harbour of Buenos Ayres, fixes the minimum flow of the River Plate at 670,000 cubic feet per second. Assuming its mean volume at 700,000 cubic feet per second (a quantity very much under the mark), it would appear that this river carries seaward some 224,000 tons of sediment every twenty-four hours-or say, in round numbers, $82,000,000$ tons every year.

Some portion of this sediment is deposited in the 100 miles of river that intervene between Buenos Ayres and the sea, forming the great banks that render the navigation of the River Plate so troublesome, but a large portion is carried out to sea and deposited beyond the mouth.

I have been informed by captains of steamers trading with Buenos Ayres that the soundings shown on the chart of the coast of Uruguay vary considerably, in many places, from the actual ones now existing, and $I$ have little doubt that a correct resurvey of this coast would show changes as" marked as those discovered by Mr. Doyle near Rangoon.

The subject is one of great importance, as the coast of Uruguay is a difficult and dangerous one to make, and from the low character of the coast, the frequency of fogs, and the great uncertainty of the currents, captains have frequently to depend a great deal on the lead to ascertain their position when making this land. During the last few years several fine steamersFrench, German, and English-have been lost on this coast near the Castillos, when making the land. GEORGE HigGiN

3, Great Greorge Street, Westminster, S.W., April Io

\section{Temperature Equilibrium in the Universe in Relation to the Kinetic Theory}

MY attention has been called 0 an ambigzous phrase in my recent paper $^{1}$ on the above subject (NATURE, vol. xix. p. 460) which it is necessary to rectify. On page $46 \mathrm{I}$ is the sentence "Let us suppose noze the excessive temperature to fall, or, in other words, the total energy to diminish." This is meant as a supposition, not as a possible case. The imaginary rise and fall of temperature in the universe are given merely for the sake of aiding the conceptions of the actual facts, by affording imaginary cases to show what the effects would be if such cases were possible.

London, April 15

S. TOLVER Preston

\section{Transportation of Seeds}

THE penetration of seeds of the so-called "flechilla" grasses into the flesh of Australian sheep is too well known to squatters. On some "runs" these grasses are so abundant that the annual loss of stock is a very serious matter. The ripe seed falls upon the wool, and, owing to the re-curved barbules with which it is armed, easily penetrates to the skin, when, its point being as sharp as a needle, every movement of the animal tends to drive

I "On the Pcssibility of Explaining the Continuance of Life in the Universe Consistent with the Tendency to Temperature-Equilibrium." it into the fiesh. I have found the internal organs so crowded with seeds that they felt like a bag of needles if squeezed in the hand. ARTHUR NICOLS

\section{Earthquakes}

A sHock of earthquake was felt in this neighbourhood on the evening of Tuesday, April 8, at 8.35 (about). We were sitting in the drawing-room of this house, when we heard a sound like the rumbling of a heavy waggon, or distant thunder. It in. creased in loudness till the room slightly vibrated and the window rattled, as it seemed to pass the house. From the peculiar nature of the sound, and the fact that we are some 50 feet above the road, and 80 or 100 yards from it, I felt certain the disturbance was due to an earthquake and not a passing waggon, but walked to the window to listen, when I heard the sound dying away in the distance. It seemed to come from the south-east, and travel towards the north-west, and to be audible, from first to last, for some seconds, perhaps five or six, because we spoke one to another during the time. I find that the shock was noticed by other people in the neighbourhood, and that in a cottage near Bettws Gormon, a mile or so from here, two glass bottles were thrown down from a high shelf and broken.

T. G. BONNEY

Bron Celyn, near Bettws y Coed, North Wales, April ro

WE were visited by an earthquake of some violence this morning at 2 A.M. (Cadiz mean time). The shock was preceded by a profound subterraneous noise like that of a distant carriage, and it extended to Port St. Mary and Port Royal (six miles) The earthquake travelled from south to north approximately; some clocks stopped.

Cadiz, April 3 Augusto T. Arcimrs

\section{OUR ASTRONOMICAL COLUMN}

Bessel's Nebula in Perseus.--On November 8, I 832 , in zone 527 , Bessel observed an object, which he recorded as a nebula, distant about one degree from 20 Persei. It is No. I,063 of 'Weisse's second Catalogue, where, though called a nebula, it has $9 \mathrm{~m}$. attached. D'Arrest, in his "Resultate aus Beobachtungen der Nebelfecken und Sternhaufen," has two observations, in January, 1856 , to the first of which he attaches a note that no nebulosity was visible in Bessel's position, and that possibly a comet was observer; the second observation records a star 9.10m., without trace of nebulosity or diameter, the place of which was found to be within a few seconds of arc from Bessel's position, preceded $24^{\circ} 22 \mathrm{~s}$. by a star $9 \mathrm{~m} . \mathrm{C}^{\prime \prime} 6^{\prime \prime}$ to the north. In "Siderum Nebulosorum," \&c., D'Arrest remarks : "Star 9m. quæ Besselio quondam nebulosa apparuit . . . Argelandro in Perlustratione ceu fixa 9.3 magn. apparuit; nobis sæpius inspicientibus nunquam nebulosa visa." This refers to the star in the "Durchmusterung," at $2 \mathrm{~h}, 43 \mathrm{~m}$. 56.5s. + $36^{\circ} 54^{\prime} 2$; Argelander has another star of the same magnitude, $9^{\prime} 3$, Io' south. Are we to infer that Bessel's star was surrounded in 1832 by nebulosity so conspicuous that it was caught at once in his zone observations, which had wholly disappeared in 1856 , or, as appears the more probable conclusion, that at the time of his meridian observation a comet happened to be centrally over the star? In this case the observation gives its place for 1832 November 8 at Ioh. Iom. 25s. G.M.T.; the catalogued 'position for $1825^{\circ} \mathrm{O}$ is in R.A. $2 \mathrm{~h} .42 \mathrm{~m} .5^{\circ} 56 \mathrm{~s}$., Decl. $+36^{\circ} 46^{\prime} 46^{\prime \prime} \cdot 7$.

This observation of Bessel's might at first sight appear of some interest, considering that the comet of the November meteors (I866 I.) must have been near perihelion about November 1832, but upon further examination it will be found that with the elements of 1866 it is not possible to bring the comet near the observed position of the "nebula," upon any assumption as to the time of its arrival in perihelion.

BRORSEN'S COMET.-Comparing the second of the two observations on April 4, in Major Tupman's letter pub- 
lished in NATURE, vol. xix. p. 527, with Dr. Schulze's elements, only with the perihelion passage assumed March 30.5716 G.M.T., the differences from observation are $\Delta a=-2^{\prime} \cdot 1$ and $\Delta \delta=+\mathrm{I}^{\prime} 3$. This position, therefore, with others obtained by Prof. Strasser and Dr. Tempel, show that when the mean anomaly is so altered as with the other elements of Dr. Schulze's orbit to bring about an exact agreement between the observed and calculated geocentric longitudes, there is still an outstanding difference between the latitudes of from one to two minutes, which indicates that, notwithstanding the apparently careful computation of the perturbations since the comet's last appearance in 1873 , the elements determining the position of the plane of the orbit are susceptible of correction. The ephemeris we gave last week will, however, amply suffice for readily finding the comet, and we shall continue it for May in our next.

Mr. Tebbutt, of Windsor, N.S.W., writes that, aided by Dr. Schulze's ephemeris, he found the comet on February 22, and observed it again in the fading twilight on the following evening. It could hardly be seen with a telescope of less than four inches aperture. It had the appearance of an elliptic nebulosity, the major axis of the ellipse extending in the direction of the parallel of declination.

New Minor Planets.--Prof. Peters, of Clinton, New York, notifies his discovery of No. 194, on March 22, in R.A. I2h. IIm., Decl. + $9^{\circ} 3 \mathrm{x}^{\prime}$, magnitude 10'5. No. 192 was found by $M$. Palisa at Pola on February 17 , and No. 193 by M. Coggia, at Marseilles, on March I.

\section{GEOGRAPHICAL NOTES}

$A \mathrm{~T}$ the metting, March 22, of the Russian Geographical Society, Col. Petroussevitch read a very interesting paper on his exploration of the Amu-daria, from Chardjui, in Bokhara, to the delta of the river, and on its former beds. M. Petroussevitch has arrived at the conclusion, based on a thorough levelling of the country, that the turning of the waters of the Amu-daria into the Sara-kamysh depression through one of the former beds, would not meet with great difficulties. This depression being, however, very wide and deep, the waters of the Amu River once arrived there, would form a great lake, and it would be difficult to direct them further to the Caspian. For this last reason it would be better to open a way for the waters of the Amu along one of its former beds which run southeast from the lake Sara-kamysh. All explorations make it very probable that in this way the Amu-daria could easily reach the Caspian. The Russian Trade Society sends, next summer, an expedition for the study of the lower parts of the Amu-daria, of the best direction for a railvay to Central Asia, and of the possibility of a canal between the Amu and the Caspian. Several officers of the Russian general staff, with geodesists, a geologist, a botanist, an archæologist, and an artist will be members of this expedition. They will start from the Ural River, passing through Kara-tugay, Tashkent, and Samarkand; further they will go down the Amu to the Uzboi.

UNDER the title of "L'Afrique Centrale en r 522 ," M. A. J. Wauters, Assistant-Secretary of the Belgian Geographical Society, has drawn up an interesting memoir, in which he has gone with much care into the doctrine of Portuguese geographers respecting the discovery of Central Africa in the sixteenth century. M. Wauters was induced to study the subject by the recent discussions in regard to the geographical data furnished by the great globe in the Lyons Library, and if anything were required to dispose of its claims to originality, this memoir does it most effectually. He traces back the idea of a great central lake, under the name of Saphat or Sachaf, to the days of Martin Hylacomilus and Gerhard Mercator, so that the data on which it was based must have been known previous to the year I522. M. Wauters's memoir appears in the current number of the Bulletin of the Belgian Geographical Society, and is illustrated by a facsimile map.

A LISBon paper gives the text of a letter which Major Serpa Pinto addressed to Sir Theophilus Shepstone from Shoshong, Bamangwato country, on January 2 , and which adds some information to that already made public respecting his adventurous journey. He states that he went beyond the Zambesi and purposed proceeding to the east coast through the country of the Choculumbes, when successive obstacles obstructed his passage. Having lost all his resources and being abandoned by his carriers, he found himself in the greatest difficulties, when fortunately he heard of a missionary who had arrived at the Upper Zambesi, and he resolved upon finding him. After a journey of 200 miles he found the missionary, M. F. Coillard, a Frenchman of the Evangelical Mission of Sesuto, Basuto-land, director of the station of Lesibo. His strength being exhausted, Major Pinto was taken seriously ill, but on his recovery succeeded in reaching: Shoshong with M. Coillard and accompanied by eight of his followers, the only ones who continued faithful.

THE Danish Government has appointed Lieut. Jensen to explore all the fjords in Greenland from Holsteinborg to the coast facing Disco. The explorations will bear on the moving ice-fields which send so many icebergs into the Polar Ocean.

MR. IM THURN paid a second visit to the Kaieteur Falls, on the Potaro River, British Guiana, in February and March last, when the river was in full flood. Referring to our remarks on his previous visit, he states that he by ho means intended to depreciate the grandeur of the fall. At his last visit he found it "so infinitely more grand, so infinitely more beautiful, that it is painfully bopeless to try to express in words anything of its beauty and grandeur." Mr. im Thurn's brief account contains several interesting notes on the botany and zoology of the region traversed.

\section{THE WOLF FISH}

F late the wolf fish (Ararrhichas lupus) has been somewhat plentiful in the Frith of Forth. A specimen which lived in the Edinburgh Aquarium for a little over a week, came into my possession a few days ago, and I have thought that an account of the dental armature of this curious fish may prove interesting to readers of NATURE. The wolf fish is a near relative of the Blennies. In this fish we see the same elongated dorsal fin, and the same anal fin as in the Blennies; but the dental arrangements of the wolf fish are of a much more specific and unusual kind than are seen in the former group. The specimen dissected measured twenty-five inches from the top of the nose to the extremity of the caudal fin. It was therefore by no means a large specimen, since from six to seven feet is not an unusual length for the sea wolf to attain. Its dark grey body was faintly banded with brown, but the head was beautifully and distinctly marbled with black on a grey ground. The aspect of the mouth, provided with its well marked teeth, partakes somewhat of a feline look, and has suggested the name "sea cat," often applied to it on these northern shores, where the fish is frequently eaten, it somewbat resembling the cod in taste. The appearance of the mouth is highly characteristic. In front of both jaws is found an array of sharp incisor teeth. The upper jaw bears five of these pointed teeth, the two lateral teeth being large, and the central three teeth small. The lower jaw possesses six teeth of similar pattern, the two central teeth being larger than the four lateral ones; and when the jaws are closed 